PALEO

Revue d'archéologie préhistorique

25 | 2014

Varia

\title{
An updated inventory of the Isturitz type bone points of the cantabrian region
}

Actualisation de l'inventaire des pointes de type Isturitz de la région cantabrique

Joseba Rios-Garaizar and Diego Garate

\section{OpenEdition}

1 Journals

Electronic version

URL: http://journals.openedition.org/paleo/3015

DOI: $10.4000 /$ paleo.3015

ISSN: 2101-0420

Publisher

SAMRA

Printed version

Date of publication: 28 December 2014

Number of pages: 233-245

ISSN: $1145-3370$

\section{Electronic reference}

Joseba Rios-Garaizar and Diego Garate, «An updated inventory of the Isturitz type bone points of the cantabrian region », PALEO [Online], 25 | 2014, Online since 28 July 2015, connection on 07 July 2020. URL : http://journals.openedition.org/paleo/3015 ; DOI : https://doi.org/10.4000/paleo.3015

This text was automatically generated on 7 July 2020 .

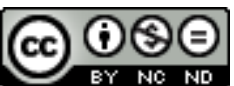

PALEO est mis à disposition selon les termes de la licence Creative Commons Attribution - Pas d'Utilisation Commerciale - Pas de Modification 4.0 International. 


\section{An updated inventory of the Isturitz type bone points of the cantabrian region}

Actualisation de l'inventaire des pointes de type Isturitz de la région cantabrique

Joseba Rios-Garaizar and Diego Garate

We wish to thank the directors of the Gipuzkoa Centre for Archaeological Material and the Archaeological Museum of Biscay for facilitating the study of the archaeological material presented in this article. Pauline Buthaud translated the Spanish manuscript into French. We also wish to thank those who reviewed this article, and in particular Cristina San Juan-Foucher, for their comments and corrections to the original manuscript.

\section{Introduction}

1 Isturitz type tools are one of the most characteristic and representative Gravettian tools in Western Europe (San Juan-Foucher and Vercoutère 2003). These tools are particularly abundant in the Pyrenees region, where they are associated with the Noailles facies of the Gravettian (Foucher 2013; San Juan-Foucher 2013), although they are also present in Dordogne (Goutas 2008; San Juan-Foucher and Vercoutère 2003), and perhaps in several sites in the north of France (Goutas 2013). In the Iberian Peninsula, this type of bone tool is only known in the Cantabrian region, and more precisely, in the east of this region. This geographical area contains a concentration of Gravettian sites rich in Noailles burins, the most important of which are, from west to east, Bolinkoba,

2 Antoliña, Amalda and Aitzbitarte III. The latter site displays clear links with the southwest of France, and in particular with the nearby site of Isturitz, as far as raw materials, techno-typology and undoubtedly the subsistence economy are concerned (Altuna et al. 2011; Normand et al. 2013). 
The number of Isturitz type points found in the Cantabrian region is very limited (fig. 1). Up until 2010, only three specimenspiecees had been identified, from Bolinkoba, Aitzbitarte III and Usategi (Corchón 1986; Mujica 1983; San Juan-Foucher and Vercoutère 2003), to which we must now add the point fragment discovered in Askondo Cave (Garate and Rios-Garaizar 2013). The distribution of these pieces in the Cantabrian region coincides with the distribution of the Gravettian rich in Noailles burins and implies that a link may exist between the eastern Cantabrian sites and those of the western Pyrenees (where Isturitz and Aitzbitarte III are the most emblematic). It is thus possible to differentiate them from those in the central and western Cantabrian zone.

4 A significant aspect of the Isturitz type points is the consistency of the technical procedures used to make them and the limited variability in shape, which is restricted to several primary types (Goutas 2008). However, their function remains uncertain as few direct functional data are available, due to the fact that only the proximal end of most of the points is intact. Therefore, functional inferences were obtained almost exclusively from the morphology of the pieces, the position and the nature of certain specific characteristics, such as dorsal and lateral striations or notches.

Figure 1 - Map showing the archaeological sites with Isturitz type points around the Bay of Biscay. Modified after N. Goutas 2008. Map modified after the original by Eric Gaba.

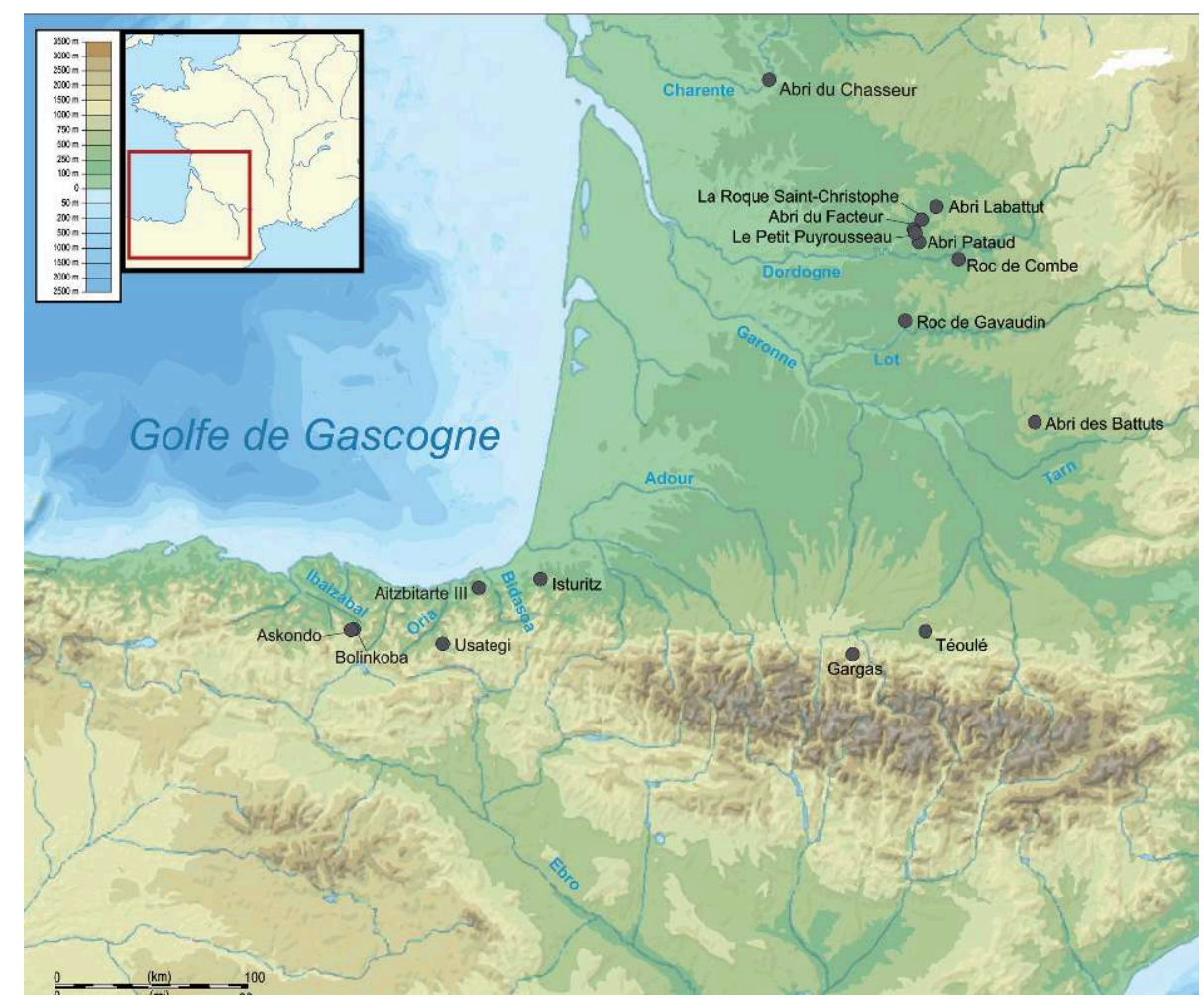

During the course of this study, we are going to conduct a technological and functional description of the Isturitz type points from the Iberian Peninsula in relation with their archaeological contexts. This will enable us to evaluate the importance of these pieces for understanding the Gravettian in the Cantabrian region and any possible links with the Pyrenees sites. 


\section{1 - Materials and Methods}

We used the methodology proposed by N. Goutas (2008) in order to describe the objects. The points were observed visually and with Olympus SZX1 and Nikon stereomicroscopes at the Arkeologi Museoa - Biscay Archaeological Museum (Bilbao) and the Gipuzkoa Centre for Archaeological material (Saint-Sebastien). In addition, we provide the maximum point dimensions, as well as the thickness and the width at different distances from the proximal end to evaluate the degree of thinning (tab. 1). The morphological and technological characteristics are summarized in table 2.

\section{1 - Askondo}

7 Up until now, this piece represents the most western discovery of an Isturitz point. It was found on the surface of Askondo Cave, located on the edge of Urkiola National Park, in the 1980s. Later, in 2010, an important complex of "pre-Magdalenian" art was discovered in the same cave, dated to $23760 \pm 110$ uncal BP (14C AMS, Beta -303671), based on the 14C AMS analysis of a bone stuck in the wall near a decorated panel (Garate and Rios-Garaizar 2013). Moreover, in the entrance of this site, an archaeological sequence composed of Middle Paleolithic levels, as well as several levels dated between 31000 and 17000 BP (Rios-Garaizar; Garate, Regalado 2012), were discovered. The point was curated in the Hontza Museoa until 2011 and is currently stored in the Arkeologi Museoa in Bilbao. The piece is well conserved, but bears a recent fracture on one end and is covered with varnish, which makes observation difficult (fig. 2). For this reason, the raw material was initially determined as bone (Rios-Garaizar and Mozota Holgueras 2012), then after more detailed examination, as antler.

The point is fusiform, with parallel edges in the central zone and convergent edges in the proximal zone. The pointed proximal end is slightly offset in relation to the longitudinal axis of the piece, creating a typical lateral bevel morphology. The section is biconvex and the upper and lower surfaces converge at an angle of $80^{\circ}$.

The -1489546594 debitage method probably began with grooving the antler, and then the blank was undoubtedly extracted by a fracture produced by bending, although no technical marks allow us to confirm this.

10 The blank was shaped by scraping the outer antler surface, thereby creating a relatively smooth surface (fig. 2a). This scraping is much more intensive and regular on the surfaces near the edges to form an angle. On the lower surface, the scraping is less intensive and part of the spongy tissue is preserved. Characteristic incisions were then made on the upper surface and on the edges of the proximal third of the piece (fig. 2c, b). On the upper surface, the incisions are fine, not very deep, and transverse to the longitudinal axis. On the edges, the incisions are deeper and shorter $(5-2.7 \mathrm{~mm})$ and do not occur at regular intervals.

\section{2 - Bolinkoba}

11 At the site of Bolinkoba, located in the same mountainous massif as Askondo, a proximal fragment of an Isturitz type point was found in level F. This level presents a high density of objects, with 760 retouched lithic pieces, dominated by burins, 
including 50 Noailles type burins. There are also La Gravette points and Vachons points. The bone industry is also abundant, with pointed bone shardschips and rib fragments decorated with series of lateral incisions, which are similar to those from Isturitz (San Juan-Foucher 2013). The assemblage also contains personal ornaments made on Littorina and Nassa reticulata shells (Garate 2012). The fauna is mainly made up of ibex, with significant carnivore presence, including the fox, the panther, the wolf and the bear (Castaños 1983). The point is currently kept in the reserve of the Arkeologi Museoa in Bilbao. The piece is well conserved, although it presents several recent fractures (fig. $3 b$ ), which probably occurred during excavation, as well as slight corrosion on the upper surface (fig. 3c).

The morphology of the preserved end of the piece is triangular, with the two edges converging at the longitudinal axis. The whole piece was probably fusiform. The section is biconvex and asymmetric, the upper and lower surfaces of the left edge converge to form an acute bevel, whereas the right edge is chamfered.

The piece presents technological marks linked to the blank extraction process, consisting mostly of grooving traces (fig. $3 \mathrm{j}$ ). The point was then shaped by two scraping phases; one of coarse scraping and a second of finer scraping or abrasion, which almost totally erased the first. This scraping affects the whole of the upper surface and only part of the lower surface, thereby preserving part of the spongy antler tissue. After that, incisions were made on the edges and the upper surface of the proximal end of the piece. These consist of simple, or at times, multiple lines

Table 1 - Measurements of the analyzed Isturitz type points.

\begin{tabular}{|l|c|c|c|c|}
\cline { 2 - 5 } \multicolumn{1}{c|}{} & Askondo & Bolinkoba & Usategi & Aitzbitarte III \\
\hline Longueur & 96 & 84 & 84 & 142 \\
\hline Largeur & 25 & 29 & 27 & 25 \\
\hline Largeur à 2 cm de l'extrémité proximale & 13 & 14 & 16 & 14 \\
\hline Largeur à 4 cm de l'extrémité proximale & 20 & 23 & 22 & 17 \\
\hline Épaisseur & 10 & 12 & 19 & 10 \\
\hline Épaisseur à 2 cm de l'extrémité proximale & 9 & 9 & 12 & 8 \\
\hline Épaisseur à 4 cm de l'extrémité proximale & 10 & 11 & 14 & 9 \\
\hline Poids (en grammes) & 14.8 & 15.5 & 25.1 & 26.3 \\
\hline
\end{tabular}


Table 2 - Morphological and technological features of analyzed Isturitz type points.

\begin{tabular}{|c|c|c|c|c|}
\hline & Askondo & \begin{tabular}{|l|} 
Bolinkoba \\
\end{tabular} & Usategi & Aitzbitarte III \\
\hline \multicolumn{5}{|l|}{ Morphologie } \\
\hline Fusiforme & $\mathrm{x}$ & & & $\mathrm{x}$ \\
\hline Triangulaire & & $\mathrm{x}$ & $\mathrm{x}$ & \\
\hline Pointe à méplat latéral & $\mathrm{x}$ & & & $\mathrm{x}$ \\
\hline \multicolumn{5}{|l|}{ Section } \\
\hline Biconvexe & $\mathrm{x}$ & $\mathrm{x}$ & & $\mathrm{x}$ \\
\hline Ovalaire/Rectangulaire & & & $\mathrm{x}$ & \\
\hline \multicolumn{5}{|l|}{ Bords } \\
\hline Encoches latérales & $?$ & & $\mathrm{x}$ & \\
\hline Chanfrein gauche & & & $\mathrm{x}$ & \\
\hline Chanfrein droit & & $\mathrm{x}$ & $\mathrm{x}$ & \\
\hline Biseau & $\mathrm{x}$ & $\mathrm{x}$ & & $\mathrm{x}$ \\
\hline \multicolumn{5}{|l|}{$\begin{array}{l}\text { Incisions face } \\
\text { supérieure }\end{array}$} \\
\hline Série unique & & $\mathrm{x}$ & & \\
\hline Série multiple & $?$ & & $\mathrm{x}$ & $\mathrm{x}$ \\
\hline \multicolumn{5}{|l|}{ Incisions droit } \\
\hline Séparées & $\mathrm{x}$ & $\mathrm{x}$ & & $\mathrm{x}$ \\
\hline \multicolumn{5}{|l|}{ Superposées } \\
\hline Série unique & $\mathrm{x}$ & & & \\
\hline Série multiple & & $\mathrm{x}$ & & $\mathrm{x}$ \\
\hline \multicolumn{5}{|l|}{ Régulières } \\
\hline \multicolumn{5}{|l|}{ Incisions gauche } \\
\hline Séparćes & $\mathrm{x}$ & $\mathrm{x}$ & & $\mathrm{x}$ \\
\hline Superposées & & & $\mathrm{x}$ & \\
\hline Série unique & $\mathrm{x}$ & $\mathrm{x}$ & & $\mathrm{x}$ \\
\hline Série multiple & & & $x$ & \\
\hline Régulières & & $\mathrm{x}$ & & $\mathrm{x}$ \\
\hline \multicolumn{5}{|l|}{ Fractures } \\
\hline Distale en languette & & & $\mathrm{x}$ & $\mathrm{x}$ \\
\hline Proximale en languette & & & & $\mathrm{x}$ \\
\hline Récente & $\mathrm{x}$ & & & \\
\hline
\end{tabular}

Figure 2 - Isturitz type point from Askondo.

a
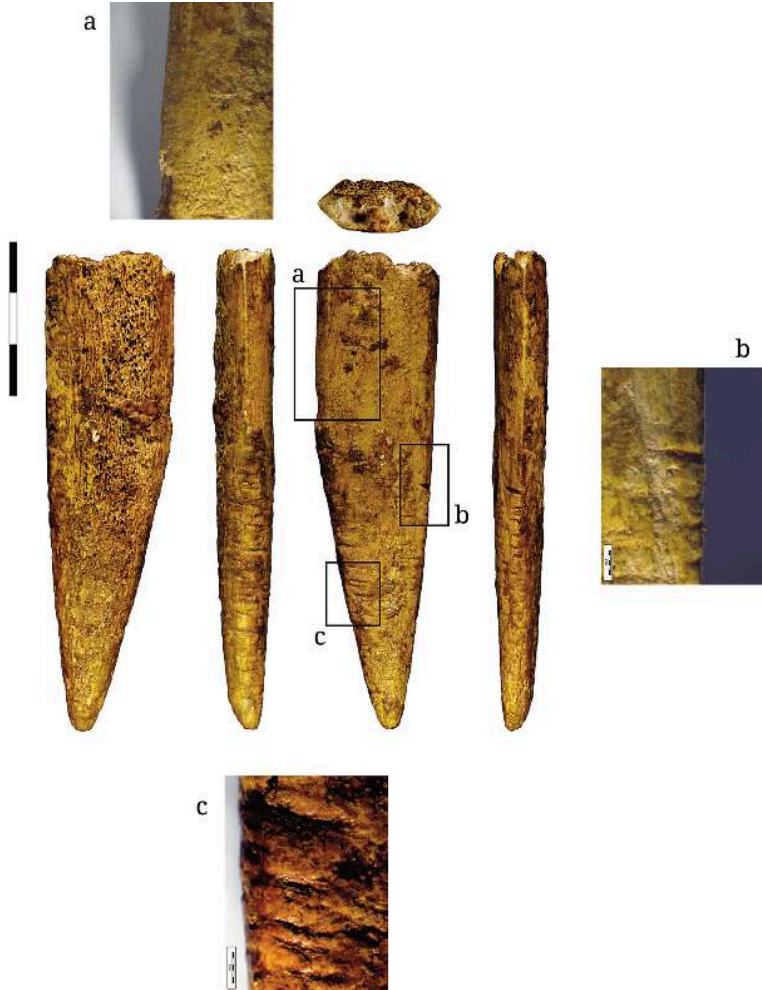
Figure 3 - Isturitz type point from Bolinkoba.
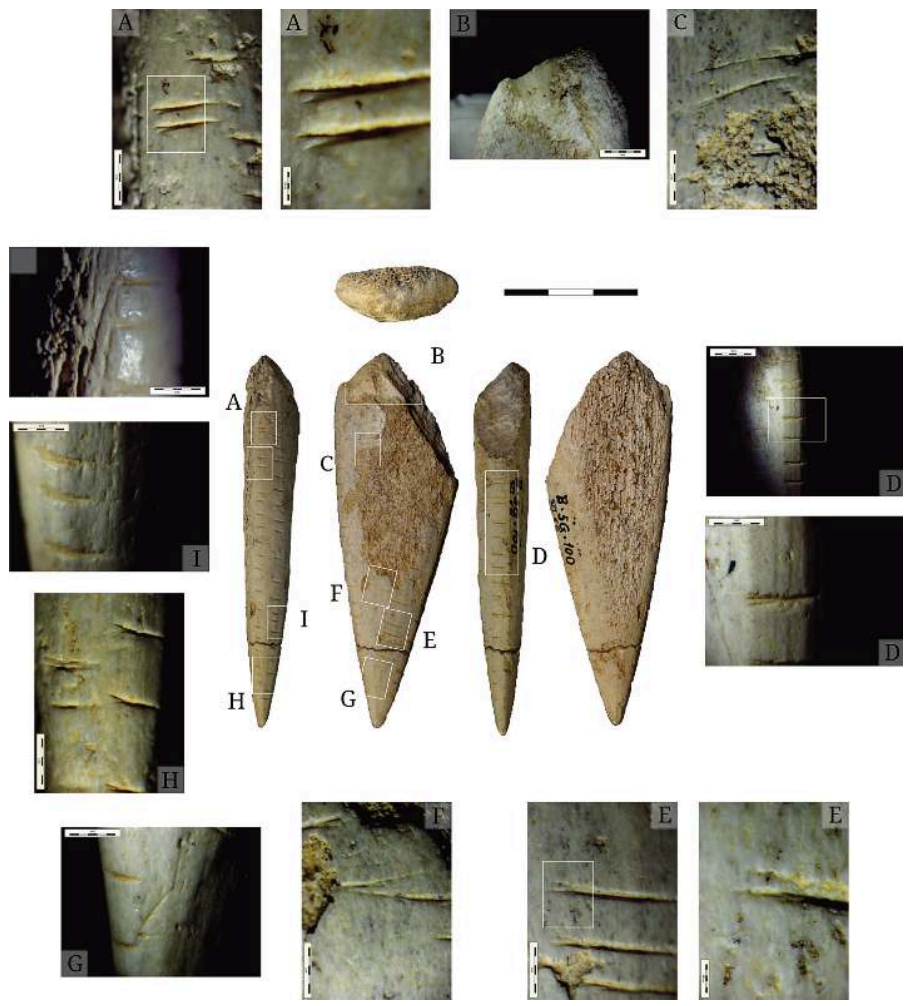

Relatively deep and short (6 $\mathrm{mm}$ ) parallel incisions (fig. $3 \mathrm{f}$, e), transverse to the longitudinal axis of the piece, were made on the upper surface. On the surface furthest from the point, these incisions seem to be finer and longer, but as this part of the piece is badly conserved, we cannot confirm this categorically (fig. 3c). The incisions on the left and right lateral edges are different. On the right edge, the incisions are very short $(<3 \mathrm{~mm})$, and are made from the lower surface and from the upper surface, positioned face to face (fig. 3a, g, h, i). On the left edge, a single series of deep incisions appears, made at regular intervals (fig. $3 \mathrm{~d}$ ). There are no parallel incisions on the ventral surface.

\section{3 - Usategi}

The site of Usategi Cave is located at the source of Oria Valley. Excavations carried out by J. M. Barandiarán in the 1970s brought to light a stratigraphy with five levels. In level III, a fragment of an Isturitz point was discovered among several lithic and bone remains (Barandiarán 1977). This piece is currently conserved in the Gipuzkoa Centre forArchaeological Material in Saint-Sebastien. It is a proximal fragment of a cervid antler point. The fracture is ancient and concerns the medial proximal part of the piece. In addition, the piece displays alteration resulting from the corrosion of the upper surface, which eliminated part of the compact tissue (fig. 4).

The point is sub-triangular in shape. The edges converge along the longitudinal axis of the piece. The section is rectangular with rounded angles.

The point does not bear any technical traces due to the extraction process, but it is possible to observe shaping marks. We observe intense longitudinal scraping by a lithic tool on the dorsal surface (fig. $4 \mathrm{~b}$ ), which slightly reduces the spongy tissue on the 
lower surface. After shaping by scraping, transverse incisions on the upper surface were made with a lithic tool. They are irregularly distributed on the upper surface, are absent along the $12 \mathrm{~mm}$ of the proximal end and less dense on the zone near the medial-distal fracture. These incisions are organized into three longitudinal bands: they are difficult to observe on the left band, due to the alteration of the upper surface (fig. 4f), they are transversal on the central band (fig. $4 \mathrm{~b}$ ) and slightly oblique on the right band (fig. 4e, c). The right incisions were made first, from right to left in a single movement. Those on the central band cut into the latter and were recut, sometimes by a back and forth movement (fig. 4c). The incisions on the left band seem to cut into those on the central band. After that, two notches were made on the right edge (fig. $4 \mathrm{~d}$ ), cutting into the incisions on the right band of the upper surface (fig. $4 \mathrm{~d}, \mathrm{e}$ ). The nearest notch to the point measures $13 \times 8 \mathrm{~mm}$, whereas the second, which seems larger, is only partially conserved (9x7.5 mm).

These notches were made by tapping with a lithic tool, from the distal end towards the proximal end, generating an asymmetrical $\mathrm{V}$ profile, with more pronounced tilting towards the proximal part. To finish it off, the left edge was first chamfered by longitudinal scraping, and then very deep incisions were made all along the edges, transverse to the longitudinal axis, following a rectilinear alignment (fig. 4a). Spacing between the incisions is not regular and the latter even overlap in several places, particularly in the zone nearest the fracture.

The piece presents a crushed tonguehinge type fracture and the distal end is slightly polished, probably due to use.

\section{4 - Aitzbitarte III}

Aitzbitarte III is located on a hill bearing the same name, at the eastern end of the Cantabrian region. The excavations undertaken during the course of the 1980s and 1990s by J. Altuna brought to light an interesting early Upper Palaeolithic sequence (Altuna 2011). The point was discovered in a gallery linking Aitzbitarte III and Aitzbitarte II, which also contained abundant fauna and lithic material, including several Noailles burins (Mujica 1983). This infilling was thought to derive from the first cave, which contained Noailles levels dated to around 24500 uncal BP (Altuna 1992). The point was published by J.A. Mujica (1983) and is currently in the Gipuzkoa Centre for Archaeological Material. It is made in cervid antler and presents an ancient distal fracture, an ancient proximal fracture and a modern fracture on the latter. The piece was consolidated, particularly the spongy tissue, as it was very fragile when it was discovered (fig. 5).

21 The shape of the point is fusiform, with parallel edges until $6.3 \mathrm{~cm}$ from the proximal end, where they begin to converge asymmetrically. The right edge presents the most marked slope, in such a way that the point is offset to the left of the longitudinal axis. The section is convex-concave. On the medial end, with parallel edges, the right edge bevel is more marked while that of the left edge is a little more rounded. Towards the proximal end, the bevels become lateral ledges, with the right edge sloping towards the upper surface and the left towards the lower surface.

The piece does not bear any technical traces linked to the extraction of the blank but nonetheless presents abundant shaping marks. Two differentiated scraping phases are visible on the upper surface; one is coarser, probably intended to eliminate the rough 
outer surface of the antler, and the other is finer, and probably results from finishing abrasion (fig. 5a, b). The spongy tissue is conserved on the lower surface.

Figure 4 - Isturitz type point from Usategi.
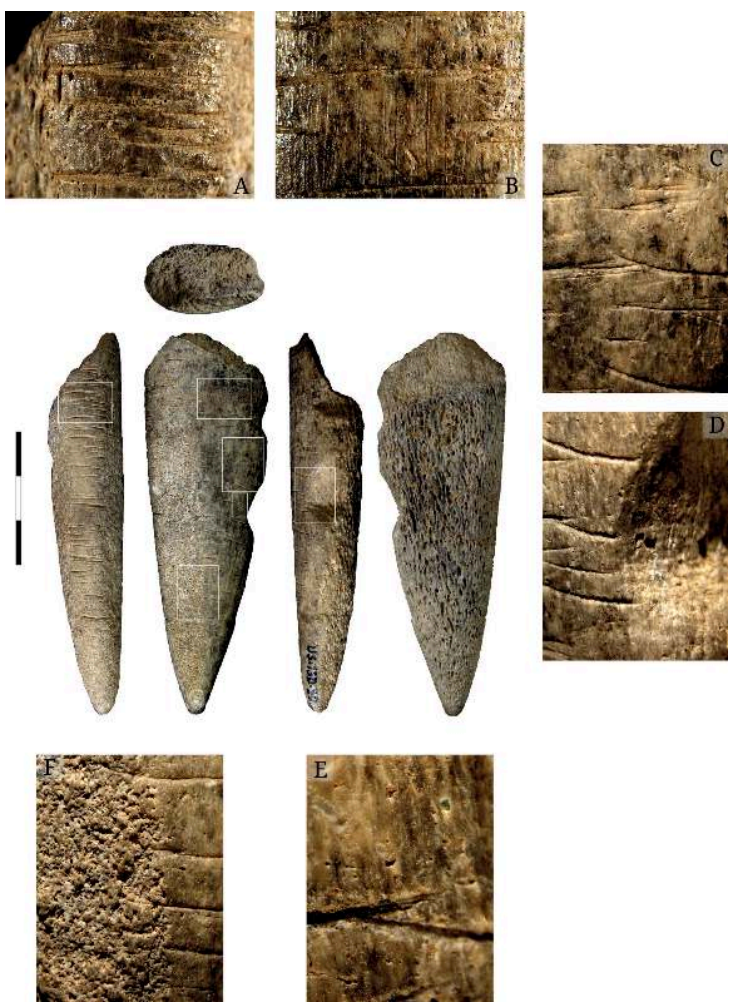

Figure 5 - Isturitz type point from Aitzbitarte III.
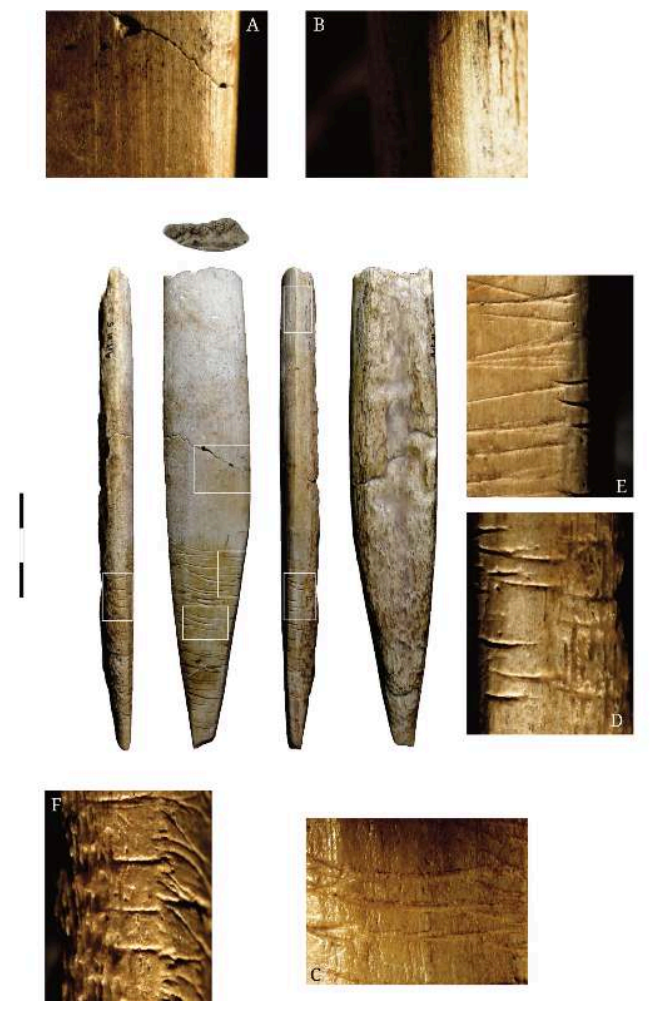

PALEO, 25 | 2014 
23 After scraping, incisions were made on the upper surface and on the edges. The incisions on the upper surface and the edges start on the proximal end of the piece and end $6.5 \mathrm{~cm}$ from the point, in the medial part of the piece where the lateral edges are parallel. The incisions on the upper surface are transverse and cover the whole width of the upper surface, and even overlap in places (fig. 5c, e). The alignment of these incisions is slightly convex towards the proximal end and they are formed by fine, single and relatively shallow lines, running from right to left. In addition, other shorter and very shallow lines start on the edges and run from right to left, overrunning very slightly onto the upper surface (fig. 5e). The right edge bears multiple incisions. Some of them are small and short and begin at the intersection with the upper surface, cutting into the incisions there. Others are longer and cover the whole thickness of the edge, whereas other short incisions start at the intersection with the lower surface (fig. 5d). These lines are clearly individualized; they do not overlap and are not separated by regular spacing. On the left edge, only a series of short lines separated by regular intervals is visible (fig. $5 f$ ). The piece presents a distal tonguehinge type fracture as well as a small proximal tonguehinge type fracture.

\section{2 - Discussion}

The presence of Isturitz type points in the Cantabrian region was initially observed by J.-M. Barandiarán, who directed excavations at Bolinkoba and Usategi, where these objects were discovered in a clear-cut archaeological context (Barandiarán 1977, 1978). After this, the point from Aitzbitarte III, excavated by J. Altuna, was added to the inventory, but this time without a clear archaeological context (Mujica1983). The point from Askondo was discovered at about the same time, but it was only identified as such and studied in 2011 (Rios-Garaizar and Mozota Holgueras 2012).

The two points recovered from level G (Gravettian) at the Asturian site of Cueto de la Mina (De la Rasilla and Santamaria 2006) have several points in common with the Isturitz type points, but cannot be classified with the latter as they present multiple differences. The proximal end of the Isturitz type points is pointed, whereas it is rounded for those from Cueto de la Mina. Neither of the Cueto de la Mina points presents the typical fusiform or triangular shapes of the Isturitz type points. The spongy bone or antler tissue is not conserved and although they present incisions on the proximal part of the piece, these are very deep and their layoutplacement is different to those of the Isturitz type points. Another remarkable piece is the proximal point fragment recovered from level XI (Lower Magdalenian) of Las Caldas Cave (Corchón 1994), also in Asturias. It is made on bone and fulfillsfulfils all the required formal and technical conditions (pointed shape, smoothed quadrangular section, multiple fine incisions on the upper surface and on the edges) to be classified as an Isturitz type point.

However, the presence of this piece in a Magdalenian level is difficult to explain as it is the only specimen of this type recovered from a clearly non-Gravettian context. Lastly, the presence of antler point fragments with an oval-shaped section was cited at the site of Antoliñako Koba. These are similar to the Isturitz type points but do not bear the typical incisions on the proximal end (Aguirre 2013, fig. 4: 1-5). However, these incisions are present on the base of a flattened point (Aguirre 2013, fig. 4: 6). 

pieces from the Cantabrian region with morphologies perfectly in keeping with the Isturitz type points found directly in Gravettian contexts (Aitzbitarte III and Bolinkoba). The point from Askondo was associated with a Gravettian archaeological and rock art context but the archaeological context is nonetheless unclear. Finally, for the piece from Usategi, the assemblage was attributed to the Gravettian on the basis of the presence on the Isturitz type point and no other archaeological elements confirm this attribution.

Isturitz type points display relative formal variability, as regards morphology, section type and the layoutplacement of the dorsal and lateral incisions, as shown during revision work on this type of tool (Goutas 2008; San Juan-Foucher and Vercoutère 2003; San Juan-Foucher 2013). The four points found in the Cantabrian sites also show variability, from both a morphometric and morphological point of view. They consist of fusiform (Aitzbitarte III-AI and Askondo-AZ) and triangular pieces (Bolinkoba-B and Usategi- U), with offset (AI, AZ) or centred points (B, U); with biconvex / oval-shaped sections (AI, AZ, B) or rectangular with rounded sides (U), and with chamfered (B, U) or beveled edges (AI, AZ, B). The incisions on the upper surface can be isolated (B), or clustered in bands (AZ, U, AI). Those on the edges can be separate, overlapping, in single or multiple series and can be spaced out at regular or irregular intervals. On the same piece, there can be differences between the types of incisions on both edges ( $t a b$. 2). From a morphometric point of view, the fusiform points (AI, AZ) correspond to the standard width of the points from the Isturitz site, whereas the two triangular pieces are similar to the maximal values. Thickness is also similar to the average Isturitz values $(9.9 \mathrm{~mm}$ ) (Goutas 2008), apart from the case of Usategi, for which the thickness of $19 \mathrm{~mm}$ is well above average.

Although the analyzed points display wide variability, this is less accentuated than at Isturitz. It is thus difficult to use the classification applied by N. Goutas (2008), particularly when the absence of distal fragments is taken into consideration. The only possible classification in this context is to differentiate the light fusiform pieces (AI, AZ) from the massive triangular pieces $(\mathrm{B}, \mathrm{U})$.

30 As far as tool function is concerned, the contribution of these four pieces is limited. Two of them present crushed tonguehinge type fractures which can be linked to projectile point use (AI, U), while the two others bear recent fractures on the proximaldistal part of the piece, making functional interpretation difficult (AZ, B). It is important to point out that the longitudinal axis is not curved, which is a favorablefavourable shape for use as projectile points.

31 As far as the context of these pieces is concerned, Aitzbitarte III and Bolinkoba both yielded intensive Gravettian occupations with Noailles burins, ornamental objects and a "domestic" bone industry. Both sites are in steep settings, overlooking valleys and present characteristics pointing to their use as habitationshabitats. However, if we compare them to Isturitz, it seems that these sites have a less important functional status. Usategi and Askondo are rather different cases. At Usategi, the archaeological context of the point is scant and not very characteristic, whereas the cave of Askondo only appears to have been used during the Gravettian for parietal art. 


\section{3 - Conclusions} regions and industrial complexes, showed stronger links in the Cantabrian region during the Gravettian, than between the southwest of France and the eastern part of the Cantabrian region (Garate et al. in press). Significant advances in our knowledge of the Gravettian in the Cantabrian region over the past decades, allow for a better understanding of the Gravettian techno-complex as well as its links with other neighboringneighbéjaouring regions. This modest contribution enables us to establish the role of Isturitz type points more clearly in this discussion.

\section{BIBLIOGRAPHY}

AGUIRRE M. 2013 - Ocupaciones gravetienses de Antoliñako koba: aproximación preliminar a su estratigrafía, cronología e industrias. In : C. de las Heras, J. A. Lasheras, A. Arrizabalaga, M. De la Rasilla (Eds.), Pensando El Gravetiense: Nuevos Datos Para La Región Cantábrica En Su Contexto Peninsular Y Pirenaico. Madrid, Ministerio de Educación, Cultura, p. 216-228 (Monografías Del Museo Nacional Y Centro de Investigación de Altamira, № 23).

ALTUNA J. 1992 - Dataciones de radiocarbono para el Perigordiense Superior del País Vasco. Munibe 43, p. 31-32.

ALTUNA J. 2011 - Las cuevas de Aitzbitarte (Landarbaso, Rentería). Situación e historia de las investigaciones. In : J. Altuna, K. Mariezkurrena, J. Rios-Garaizar (Eds.), Ocupaciones Humanas En La Cueva de Aitzbitarte III (Renteria, País Vasco) Sector Entrada: 33.000-18.000 BP. Vitoria-Gasteiz, Eusko Jaurlaritzaren Argitalpen Zerbitzu Nagusia, p. 11-21.

ALTUNA J., MARIEZKURRENA K., RIOS-GARAIZAR J. 2011 - Ocupaciones Humanas en la Cueva de Aitzbitarte III (Renteria, País Vasco) Sector Entrada 33 000-18 000 B. Vitoria-Gasteiz, Eusko Jaurlaritzen Argitalpen Zerbitzu Nagusia. 
ARRIZABALAGA A., DE LA PEÑA P. 2013 - El registro de la industria lítica como base para la organización del Gravetiense cantábrico. In : C. de las Heras, J. A. Lasheras, A. Arrizabalaga, M. De la Rasilla (Eds.), Pensando El Gravetiense: Nuevos Datos Para La Región Cantábrica En Su Contexto Peninsular Y Pirenaico. Madrid, Ministerio de Educación, Cultura, p. 367-386 (Monografías Del Museo Nacional Y Centro de Investigación de Altamira, № 23).

ARRIZABALAGA A., CALVO A., ELORRIETA I., TAPIA J., TARRIÑO A. 2014 - Where To and What For? Mobility Patterns and the Management of Lithic Resources by Gravettian Hunter-Gatherers in the Western Pyrenees. Journal of Anthropological Research, 70, p. 233-261.

BARANDIARÁN J.M. 1977 - Excavaciones en Jentilbaratza y Kobalde (Ataun) (Campaña de 1971). Munibe 29, p. 195-212.

BARANDIARÁN J.M. 1978 - Bolinkoba y otros yacimientos prehistóricos de la Sierra de Amboto. In : J. M. Barandiarán (Ed.), Obras Completas de José Miguel de Barandiaran Tomo XII. Bilbao, La Gran Enciclopedia Vasca, p. 393-453.

CASTAÑOS P. 1983 - Estudio de los macromamíferos del yacimiento prehistórico de Bolinkoba. Kobie 13, p. 261-298.

CORCHÓN M. S. 1986 - El arte mueble paleolítico cantábrico: contexto y análisis interno. Madrid, Subdirección General de Arqueología y Etnografía.

CORCHÓN M. S. 1994 - Arte mobiliar e industria ósea solutrense en la Cornisa Cantábrica. Férvedes 1, p. 131-148.

DE LA RASILLA M., SANTAMARÍA D. 2006 - El Gravetiense del Abrigo de Cueto de la Mina (Posada de Llanes, Asturias). Zona Arqueológica, Miscelánea en Homenaje a Victoria Cabrera 1, p. 422439.

FOUCHER P. 2013 - Synthèse chrono-culturelle sur le Gravettien des Pyrénées: constat et réflexions sur la stabilité régionale des traditions techniques. In : C. de las Heras, J. A. Lasheras, A. Arrizabalaga, M. De la Rasilla (Eds.), Pensando El Gravetiense: Nuevos Datos Para La Región Cantábrica En Su Contexto Peninsular Y Pirenaico. Madrid, Ministerio de Educación, Cultura, p. 151-168 (Monografías Del Museo Nacional Y Centro de Investigación de Altamira, № 23).

FOUCHER P., SAN JUAN-FOUCHER C., VERCOUTÈRE C., FERRIER C. 2012. La grotte de Gargas (Hautes-Pyrénées, France) : l'apport du contexte archéologique à l'interprétation de l'art pariétal. In J. Clottes (dir) L'art pléistocène dans le monde / Pleistocene art of the world / Arte pleistoceno en el mundo. Actes du Congrès IFRAO, Tarascon-sur-Ariège, 6-11 septembre 2010. $N^{\circ}$ spécial de Préhistoire, Art et Sociétés, Bulletin de la Société Préhistorique Ariège-Pyrénées, LXV-LXVI, 2010-2011, livre : p. 52-53 et CD : p. 209-225.

GARATE D. 2012 - Neandertales y Cromañones. Los primeros pobladores de Bizkaia. Guías del Arkeologi Museoa, 2. Bilbao, Diputación Foral de Bizkaia, Bizkaikoa y Arkeologi Museoa.

GARATE D., RIOS-GARAIZAR J. 2013 - El arte parietal paleolítico de la cueva de Askondo (Mañaria, Bizkaia. In : C. de las Heras, J. A. Lasheras, A. Arrizabalaga, M. De la Rasilla (Eds.), Pensando El Gravetiense: Nuevos Datos Para La Región Cantábrica En Su Contexto Peninsular Y Pirenaico. Madrid, Ministerio de Educación, Cultura, p. 512-525 (Monografías Del Museo Nacional Y Centro de Investigación de Altamira, № 23).

GARATE D., RIVERO O. 2014 - L'art mobilier gravettien sur support lithique de la grotte d'Isturitz (Saint-Martin-d'Arberoue, Pyrénées-Atlantiques) : une collection redécouverte. Paleo ${ }^{\circ}$ 25, p. 247-276 
GARATE D., RIVERO O., RUIZ-REDONDO A., RIOS-GARAIZAR J. sous presse - In the crossroads: New findings of rock art around the Biscay Bassin for the understanding of paleolithic symbolic expression. Quatenary International.

GOUTAS N. 2008 - Les pointes d'Isturitz sont-elles toutes des pointes de projectile? Gallia Préhistoire 50, p. 45-101.

GOUTAS N. 2013 - Nouvelles données sur l'industrie osseuse du gravettien des grottes d'Arcy-surCure (Yonne, France) : vers l'identification de nouveaux marqueurs techniques et culturels du Gravettien moyen à burins du Raysse. In : P. Bodu, L. Chehmana, L. Klaric, L. Mevel, S. Soriano, N. Teyssandier (Eds.), Actes de La Table Ronde Internationale: Le Paléolithique Supérieur Ancien de l'Europe Du Nord-Ouest. Séance de La Société Préhistorique Française (15-18 Avril 2009, Musée de Sens, Yonne). Paris, Societé Préhistorique Française, p. 89-115.

MUJICA J. A. 1983 - Industria de hueso en la prehistoria de Gipúzcoa. Munibe 35, p. 451-631.

NORMAND C., GOUTAS N., LACARRIERE J., SIMONET A. 2013 - El Gravetiense de Isturitz : nuevas investigaciones, nuevos datos. In : C. de las Heras, J. A. Lasheras, A. Arrizabalaga, M. De la Rasilla (Eds.), Pensando El Gravetiense: Nuevos Datos Para La Región Cantábrica En Su Contexto Peninsular Y Pirenaico. Madrid, Ministerio de Educación, Cultura, p. 171-194 (Monografías Del Museo Nacional Y Centro de Investigación de Altamira, № 23).

RIOS-GARAIZAR J., MOZOTA M. 2012 - Estudio de la industria lítica, ósea y cerámica del yacimiento de Askondo (Mañaria, Bizkaia). In : D. Garate, J. Rios-Garaizar (Eds.), La Cueva de Askondo (Mañaria, Bizkaia). Arte Parietal Y Ocupación Humana Durante La Prehistoria. Kobie. Bilbao, Diputación Foral de Bizkaia, p. 77-88. (Serie BAI, 2).

RIOS-GARAIZAR J., DE LA PEÑA P., SAN EMETERIO A. 2011 - Estudio de las industrias líticas y óseas de la cueva de Aitzbitarte III (Zona de la entrada). In : Altuna, J., Mariezkurrena, K., RiosGaraizar, J. (Eds.), Ocupaciones Humanas En La Cueva de Aitzbitarte III (Renteria, País Vasco) Sector Entrada: 33.000-18.000 BP. Eusko Jaurlaritzaren Argitalpen Zerbitzu Nagusia, Vitoria-Gasteiz, p. 81351.

RIOS-GARAIZAR J., GARATE D., REGALADO E. 2012 - Excavación arqueológica en la cueva de Askondo (Mañaria, Bizkaia). In : D. Garate, J. Rios-Garaizar (Eds.), La Cueva de Askondo (Mañaria, Bizkaia). Arte Parietal Y Ocupación Humana Durante La Prehistoria. Kobie. Bilbao, Diputación Foral de Bizkaia, p. 31-38. (Serie BAI, 2).

SAN JUAN-FOUCHER C. 2013 - Industria ósea decorada y arte mueble del Gravetiense Pirenaicoriales actualizadas. In : C. de las Heras, J. A. Lasheras, A. Arrizabalaga, M. De la Rasilla (Eds.), Pensando El Gravetiense: Nuevos Datos Para La Región Cantábrica En Su Contexto Peninsular Y Pirenaico. Madrid, Ministerio de Educación, Cultura, p. 461-483 (Monografías Del Museo Nacional Y Centro de Investigación de Altamira, № 23).

SAN JUAN-FOUCHER C., VERCOUTÈRE C. 2003 - Les « sagaies d'Isturitz » des niveaux gravettiens de Gargas (Hautes-Pyrénées) et de Pataud (Dordogne). Préhistoires Méditerranéennes 12, p. 75-94.

TARRIÑO A. 2011 - Procedencia de los sílex de la cueva de Aitzbitarte III (Rentería, Gipuzkoa). In : J. Altuna, K. Mariezkurrena, J. Rios-Garaizar, J. (Eds.), Ocupaciones Humanas En La Cueva de Aitzbitarte III (Renteria, País Vasco) Sector Entrada: 33 000-18 000 BP. Eusko Jaurlaritzaren Argitalpen Zerbitzu Nagusia, Vitoria-Gasteiz, p. 353-373. 


\section{ABSTRACTS}

In this work we present a review of the Isturitz type bone point assemblage of the cantabrian Gravettian, which includes the already known pieces from Bolinkoba, Usategi and Aitzbitarte III, and also the point recently discovered in Askondo site. This review includes technological and use-wear analyses which helped to identify two major types: light fusiform points (Aitzbitarte III and Askondo) and massive triangular points (Bolinkoba and Usategi). Also, we noted that the spatial distribution of the Isturitz type points in the cantabrian region is similar to the distribution of the sites defined as Gravettian rich in Noailles burins. This evidence, combined with the available information about raw material mobility, the technological organization and the artistic manifestations, suggest a particular territorial articulation of this region during the Gravettian.

Nous présentons dans ce travail une révision du corpus des pointes de type Isturitz du Gravettien cantabrique, concernant les exemplaires déjà connus de Bolinkoba, Usategi et Aitzbitarte III, ainsi que celui provenant de la récente découverte du site d'Askondo. L'analyse inclut une approche technologique et fonctionnelle de ces pointes grâce à laquelle nous pouvons conclure que deux types primaires sont représentés : les pointes fusiformes légères (Aitzbitarte III et Askondo) et les pointes triangulaires massives (Bolinkoba, Usategi). De plus, la distribution des sites possédant des pointes de type Isturitz dans la région cantabrique nous permet d'associer ces armatures avec celles des sites attribués au Gravettien riche en burins de Noailles. Ceci, avec d'autres éléments tels que la mobilité des matières premières, la technologie lithique ou les manifestations artistiques, nous permet d'y repérer une articulation territoriale particulière pendant le Gravettien dans cette région.

INDEX

Mots-clés: Gravettien, pointe de type Isturitz, industrie osseuse, territorialité, région cantabrique

Keywords: Gravettian, Isturitz type point, bone industry, territoriality, cantabrian region

\section{AUTHORS}

\section{JOSEBA RIOS-GARAIZAR}

Centro Nacional de Investigación sobre la Evolución Humana (CENIEH). Paseo Sierra de Atapuerca, 3, ES-09002 Burgos - joseba.rios@cenieh.es

\section{DIEGO GARATE}

Arkeologi Museoa Calzadas de Mallona s/n, ES-48006 Bilbao - garatemaidagandiego@gmail.com 